\title{
The Role of School Factors in Predicting School Maladjustment in Junior High School Students
}

\author{
Marhsa Amirbagloie-Daryani ${ }^{*}$, Somayeh Shabani ${ }^{1}$, Soheila Saraee ${ }^{2}$, Robert Pasnak ${ }^{3}$ \\ ${ }^{1}$ Department of Psychology, Faculty of Psychology and Educational Sciences, Islamic Azad University, South Tehran Branch, \\ Tehran, Iran \\ ${ }^{2}$ Department of Psychology, Faculty of Psychology and Educational Sciences, Allameh Tabatabaei University, Tehran, \\ Iran \\ ${ }^{3}$ Department of Psychology 3F5, George Mason University, Fairfax, USA \\ Email: ^M_Daryani@azad.ac.ir
}

How to cite this paper: AmirbagloieDaryani, M., Shabani, S., Saraee, S., \& Pasnak, R. (2022). The Role of School Factors in Predicting School Maladjustment in Junior High School Students. Creative Education, 13, 135-148.

https://doi.org/10.4236/ce.2022.131010

Received: November 27, 2021

Accepted: January 17, 2022

Published: January 20, 2022

Copyright $\odot 2022$ by author(s) and Scientific Research Publishing Inc. This work is licensed under the Creative Commons Attribution International License (CC BY 4.0).

http://creativecommons.org/licenses/by/4.0/

\section{(c) (i) Open Access}

\begin{abstract}
This study was performed to determine the role of school factors in predicting school maladjustment. The statistical population was all junior high schools of a large city in 2016-2017. The School Factors Questionnaire, School Maladjustment Scale (Amirbagloie-Daryani, Ganjii, \& Sharifi, 2018), and the My Class Inventory (Fraser, Giddings, \& McRobbie, 1995) were administered to a sample of 160 of these students selected by a cluster random sampling method. Pearson correlation coefficients were calculated and a stepwise multiple regression analysis was performed. Classmate relationships, teacher-student relationships, and cohesion in the classes were negatively related to school maladjustment, and there was a significant positive relationship between friction in the classes and school maladjustment. The stepwise multiple regression showed that the predictor variables of the model explained 24 percent of the variance in school maladjustment, and that the variables of classmate relationships, teacher-student relationships, and friction in the class were the strongest factors that affected school maladjustment.
\end{abstract}

\section{Keywords}

School Maladjustment, School Factors, Psychosocial Class Atmosphere

\section{Introduction}

Academic adjustment is one of the general dimensions of adjustment. The process of academic adjustment involves behavioral and psychological changes in which individuals try to adapt to their new learning environment, successfully 
adapt to academic demands, and meet their learning needs (Baker \& Siryk, 1999; Valka, 2015). Tanyi (2002) defined an individual's academic adjustment as the person's ability to cope with academic demands and school activities.

In contrast, school maladjustment can be defined as students' negative performances in their actions to solve the tasks imposed by the educational environment and it is related to the efficiency, progress and success of the students in school. School maladjustment is primarily students' disordered relations with parents, teachers, classmates, and school staff, and related breaches of the rules of scholars and extra-scholars (Cîrceie, 2016). Maladjustment problems are often considered to be a heterogeneous set of behaviors, all of which make teaching more difficult and hinder the normal flow of the teaching-learning process in the classroom. In other words, school maladjustment usually involves a wide range of behaviors, which ultimately create problems in the educational environment (De la Fuente, Peralta, Sánchez, \& Trianes, 2012). During high school, these include but are not limited to issues such as indiscipline, academic indifference, and pestering others in class (Peralta, Sanchez, De la Fuente, \& Trianes, 2009).

School maladjustment is a phenomenon that involves many factors and is a serious obstacle to educational progress. It makes the teacher's job more difficult and predicts problems for the student (Ishee \& Alisa, 2004). Factors that determine adolescent maladaptive behavior can be traced to family environment, peers, and the cultural context of the school (Kiesner \& Kerr, 2004). School environment can affect the growth and socialization of adolescents and make them either more disciplined or less so. If the school fails to create the environment and social conditions appropriate to the needs of students in the school, unfortunate consequences such as academic failure, frequent absences from the classroom and other deviant acts are likely to result (Moidfar \& Moghimi-Esfandabadi, 2012). Inappropriate school and classroom conditions, formal and informal threats and reprimands, and repeated punishments and penalties disrupt students' emotional stability and shake their character, making them resentful, aggressive, and unbalanced. In consequence they tend to cheat, be violent, and be undisciplined, leading to poor educational performance, rejection, academic failure, behavioral problems and dropping out (Asadzadeh \& Morovvati, 2007).

Waters, Cross and Runions (2009) conducted a meta-analysis on research related to schooling that was based on Bronfenbrenner's Ecological Model (Bronfenbrenner, 1979). They presented a theoretical model in which developing connections to school are influenced by factors such as school ecology (structure, function, and "built environment"), interpersonal experience with parents, peers, and teachers, and satisfaction of basic psychological needs. In the same vein, in Bandura's theory of observational learning (Schultz \& Schultz, 2013), the environment and social context, including the school and schooling are considered to be major determinants of behavior.

School-related factors, especially the quality of the classroom context, are risk factors that can significantly increase the risk of destructive and aggressive behavior problems in school. The results obtained from experimental studies show 
that classroom contexts characterized by dissatisfied teachers and disinterested students evoke and reinforce destructive behaviors (Matthys \& Lochman, 2010). Hosseini and Latifian (2006) defined classroom climate as external conditions, forces, and motivations, including physical, social, and psychological factors. Fraser (1994) further defined classroom climate and identified dimensions which describe it. The prevailing classroom climate can be one that is full of integration or cohesion (the degree of dependence and bonding of students), a disciplined and task-oriented climate (the extent to which students do their homework on time and regularly), a climate of friction (the relative frequency of unfriendly student behavior) or a climate full of frustration and competition (the rate of students' rivalry and competition with each other).

Rajabi, Chahardolie and Attari (2007) reported that students attend to homework and learning in well-organized classes and activities. They pay attention to the teacher's guidance and follow classroom rules and procedures. Where classroom discipline and organization are low, aggression increases. Matthys and Lochman (2010) described a six-year study that showed the classroom environment could be responsible for changing student behavior. Aggressive first-grade boys who were in classes with high levels of aggression were more likely to continue high levels of aggression in later periods than aggressive boys who were in classes with low levels of aggression. Barth, Dunlap, Dane, Lochman and Wells (2004) also found that the characteristics of students in a class affect the behavior of students in that class. If students are in classes that include many aggressive students, they are in turn more likely to become more aggressive.

These studies show that school climate is an important factor that supports educational, social and emotional development of students. As students begin school and develop throughout their schooling, they are continually called upon to adjust new situations, and to attain a certain expected level of adjustment (Periasamy, 2021). Students are less likely to engage in risky behaviors at a school when they perceive the school as positive. When they perceive the school climate as less positive, they engage in more destructive behaviors. And, in general, in schools with a more positive climate, students are less likely to engage in risky behaviors (Feigenberg, 2007). Haj-Shamsayi, Kareshki and Amine-Yazdi (2014) found that the climate of competition in the classroom has an effect on students' adjustment which is mediated by self-regulation and task-oriented and cohesion climates. In general, researchers (Amanelahi, Attari, \& Khojasteh-Mehr, 2009; Periasamy, 2021; Zare-Alamshiri \& Saber, 2017; Rajabi et al., 2007) have found that that, unsurprisingly, the more appropriate the classroom climate, the lower the maladjustment of students.

Beyond this, the efficiency of schoolwork depends in part on a well-equipped building and appropriate equipment. This means that any place where a group can come together cannot be accepted as an effective classroom, and success and progress in educational matters often depends on the preparation of special arrangements and the provision of sufficient facilities and equipment. High population density is a physical factor that increases aggressive behaviors and, if it 
continues, causes pathological and abnormal reactions (Ghasemzadeh, 2016). In general, an optimal school building would meet several expectations for students and teachers. These include being spatially intimate, facilitating diverse activities, but preserving quiet, and making it possible for students to sometimes be in touch with nature. An ideal school setting would be conducive to strengthening social interaction and feelings; and also be psychologically relaxing, safe, enjoyable, playful, and uplifting. In addition, the space must be physically controllable, providing light and protection against heat, cold, light, and humidity. Behaviorally it should provide the possibility of individual study, teamwork, physical activity, writing, reading, computer work, music, theater, and play (Bagheri \& Azemati, 2011). A suitable physical environment includes items such as educational aids, sports grounds, library space, laboratory space and equipment, health service, green space, classroom appropriate desks and benches or seats. Appropriate school facilities include educational, sports, visual and extracurricular facilities (Azin \& Mosavi, 2011).

Psychosocial research in education (Bae, 2015; Dwyer, Osher, \& Hoffman, 2000) suggests that a positive perception of the school environment can help students resolve behavioral and emotional problems. Sharif, Ganji and Hajloo (2011) showed that the more favorable the school library, the better the student bonding to the school will be. On the other hand, Azin and Mosavi (2011) found that while there was a positive relationship between teacher turnover, school facilities, management style and students' social adjustment, there was no significant relationship between physical conditions in terms of teaching equipment, sports grounds, library, laboratory, etc. and students' social adjustment.

Students' relationships with teachers and classmates are also important factors influencing school maladjustment. The support that a student receives from the environment and others has positive effects and improves psychological dynamics and helps the student emotionally, cognitively and physically (Gülaçti, 2010). Musitu-Ferrer, Esteban-Ibanez, Leon-Moreno and Garcia (2019) showed that high school adjustment was related to higher cognitive and emotional environmental empathy. According to social control theory, deviation from social expectations can be due to weak attachments and disintegration of the individual's sense of belonging to society, which occurs when there is a lack of control and supervision. As a promoter of the theory of social control, Durkheim (1895/1950) believed that if social bonding was strong in a society, its members would probably conform to social values and norms, but if social bonding was weak in a society, people might tend to be criminalized. Hirschi (1969) the founder of the social bond theory, posited that unusual behavior occurs when the bond between the individual and society becomes weak and broken (cf. Sotoudeh, 2007).

The teacher is an authority figure with whom students spend much time; consequently the students may be influenced by the teacher's supportive behaviors. Relevant classroom behavior by the teacher may include such things as teaching methods, laughter and jokes, glances, greetings, praise or blame, lesson-related questions, encouraging student participation in teaching activities, 
encouragement and punishment, and discrimination in interactions with students (Azin \& Mosavi, 2011). Rohner (2010) found that the affective quality of dyadic teacher-student relationships influences students' psychological development. Children's perceptions of both parents and teachers were significantly correlated with their psychological adjustment, and perceived teacher acceptance made a unique contribution to variations in adolescents' psychological adjustments. Many other studies show that the quality of dyadic student-teacher relationships affect students' school adjustment (Azin \& Mosavi, 2011; Bae, 2015; Buyse, Verschueren, Doumen, Van Damme, \& Maes, 2008; Kuyumcu, 2020; Moidfar \& Moghimi-Esfandabadi, 2012; Roorda, Zee, \& Koomen, 2020; Rudasill, Reio, Stipanovic, \& Taylor, 2010).

Another factor in school adjustment is relationships between classmates. Because adolescents spend less time with family members, peers become increasingly important. Teenagers say they are in their best moods when they are with their friends. Friendly relationships provide opportunities to explore oneself and cultivate a deep understanding of others, helps adolescents cope with adolescent stress, and can improve school attitudes and academic performance (Berk, 2001). Barcaccia et al. (2018) found that not having a best friend had an additive effect on maladjustment. Numerous studies have confirmed the role of social support and communication with peers in student's adjustment (Afsharian \& Kadivar, 2016; Estévez, Jiménez, \& Moreno, 2018; Hosseini, 2015; Garner, Dunsmore, \& Bassett, 2020; Hejazi, Ejei, \& Ranjbar, 2013; Millings, Buck, Montgomery, Spears, \& Stallard, 2012; Saleh-Sedghpour, Asadi, \& Miri, 2011).

In sum, much research indicates that school factors such as classroom sociopsychological climate, educational facilities and space, and the quality of the student's relationship with teachers and classmates, may all play an effective role in the maladjustment of students in the school environment. In previous research one or more of these factors have been studied separately but a comprehensive study has not been reported. The main goal of the present study was to determine the relative contribution of many of these school factors in students' school maladjustment when acting and measured simultaneously on the same student sample.

Junior high school is an important transition in the educational process and in adolescent development. Hence, junior high school was the focus of this study.

\section{Method}

\section{Participants}

The statistical population included all junior high schools funded in 20162017 by a large city. From this population, a sample of 160 students (110 girls and 50 boys) were selected by a cluster sampling method. The mean age of the students was $13.64(\mathrm{SD}=0.80)$. Of these students, 98 were studying in the seventh grade $(61.3 \%), 34$ in the eighth grade $(21.3 \%)$, and 28 in the ninth grade (17.5\%).

\section{Instruments}


School Maladjustment Scale. To assess school maladjustment, the School Maladjustment Scale (Amirbagloie-Daryani, Ganji, \& Sharifi, 2018) was used. This scale consists of 88 items answered on a four-point Likert scale (never, a little, some, and often) that is completed by teachers for each student. Amirbagloie-Daryani et al. reported that the Cronbach's Alpha coefficient for reliability of this scale is 0.97 . An exploratory factor analysis for construct validity showed that this scale consists of six factors: 1 ) academic indifference and lack of attention, 2) inappropriate behaviors toward teachers and classmates, 3) destructive and undisciplined behaviors, 4) bullying and antisocial behaviors, 5) deception and violation of rules, and 6) withdrawal and victimization by bullies. Together, these six factors explained 57.80 percent of the total variance of the variables. The results of the confirmatory factor analysis indicated that the 6-factor model was supported by more than seven fit indices. The criterion validity of this scale using the Student Adjustment Inventory (Sinha \& Singh, 1995) for comparison was 0.405 .

School Factors Questionnaire. This questionnaire was developed for the present research to collect information on school-related factors that were based on the ideas in the research reviewed in the introduction to this article. It includes 15 items about school facilities, the quality of teacher-student relationships and classmate relationships. These questions were also answered on a four-point Likert scale (excellent, good, average, and poor). The content validity of the questionnaire was evaluated and confirmed based on the opinion of educational experts; the Cronbach's alpha coefficient for its reliability 0.74 .

My Class Inventory. The My Class Inventory (Fraser, Giddings, \& McRobbie, 1995) was used to examine the classroom sociopsychological climate. The questionnaire consists of 20 items that are answered in a three-point Likert scale (rarely, sometimes, and always) and includes four subscales, friction, cohesion, task-orientation (discipline), and competition. Hossenchari and Khayer (2003) reported that the Cronbach's alpha reliability coefficient for this questionnaire is 0.83 . The construct validity of this questionnaire was measured by a factor analysis method and the four primary factors were confirmed.

\section{Procedure}

The School Factors Questionnaire and My Class Inventory (Fraser et al., 1995) were administered to small groups of students after explanations on how to respond. Twenty teachers assessed the School Maladjustment Scale (Amirbagloie-Daryani et al., 2018) answers from all of the students in the sample group.

\section{Results}

Descriptive statistics, Pearson correlation coefficients and stepwise multiple regression were used to analyze the data. Means, standard deviations and correlation coefficients between school maladjustment and school factors are reported in Table 1. 
Table 1. Means, standard deviations, and correlations between school maladjustment and predictor variables.

\begin{tabular}{|c|c|c|c|c|c|c|c|c|c|c|}
\hline & & M & SD & 1 & 2 & 3 & 4 & 5 & 6 & 7 \\
\hline 1 & School maladjustment & 126.3 & 42.72 & - & & & & & & \\
\hline 2 & School facilities & 15.47 & 2.66 & 0.01 & - & & & & & \\
\hline 3 & Classmate relations & 6.6 & 1.37 & $-0.42^{\star \star}$ & $0.16^{*}$ & - & & & & \\
\hline 4 & Relations to teacher & 9.32 & 2.18 & $-0.38^{\star \star}$ & $0.23^{\star *}$ & $0.53^{\star \star}$ & - & & & \\
\hline 5 & Cohesiveness & 12.06 & 2.12 & $-0.28^{\star *}$ & $0.14^{*}$ & $0.58^{\star *}$ & $0.42^{* *}$ & - & & \\
\hline 6 & Task orientation & 8.56 & 1.19 & -0.02 & $0.25^{\star *}$ & 0.11 & $0.24^{\star *}$ & $0.20^{* *}$ & - & \\
\hline 7 & Competitiveness & 10.16 & 1.85 & 0.01 & -0.06 & 0.06 & 0.08 & 0.10 & 0.11 & - \\
\hline 8 & Friction & 8.96 & 1.87 & $0.27^{\star *}$ & 0.02 & $-0.18^{\star}$ & $-0.28^{\star *}$ & $-0.32^{\star *}$ & $-0.34^{\star *}$ & -0.01 \\
\hline
\end{tabular}

${ }^{\star} p<0.05,{ }^{* *} p<0.01$. 
Table 2. Regression results.

\begin{tabular}{|c|c|c|c|c|c|c|}
\hline Step & Predictor & $\mathrm{R}^{2}$ & $\Delta \mathrm{R}^{2}$ & B & $\beta$ & VIF \\
\hline 1 & classmate relationships & $0.18^{* * *}$ & 0.18 & $-12.95^{\star * *}$ & -0.42 & 1.00 \\
\hline \multirow{2}{*}{2} & classmate relationships & $0.22^{* * *}$ & 0.04 & $-11 / 83^{\star \star *}$ & -0.38 & 1.04 \\
\hline & Friction & & & $4.53^{\star *}$ & 0.20 & 1.04 \\
\hline \multirow{3}{*}{3} & classmate relationships & $0.24^{* * *}$ & 0.02 & $-9.14^{\star * *}$ & -0.30 & 1.04 \\
\hline & Friction & & & $3.80^{*}$ & 0.17 & 1.08 \\
\hline & teacher-student relationships & & & $-3.42^{*}$ & -0.18 & 1.47 \\
\hline
\end{tabular}

adding the teacher-student relationships there was another $2 \%$ increase. The linear combination of these three factors was able to explain a total of $24 \%$ of variance in school maladjustment. All regression coefficients of these three factors are statistically significant. Increases in the frictional climate of the class predicted increases in school maladjustment and improved classmate relationships and teacher-student relationships negatively predicted school maladjustment in students. In other words, with increases in the frictional climate of class and decreases in the quality of the relationship with classmates and teachers, the rate of school maladjustment increases. Examining the beta coefficients in the third step, it can be concluded that the classmate relationships $(\beta=-0.30)$ have the largest contribution in predicting school maladjustment in classes, followed by teacher-student relationships $(\beta=-0.18)$ and frictional climate of class $(\beta=$ $0.17)$.

\section{Discussion}

The aim of this study was to determine the role of seven school factors in predicting the school maladjustment of junior high school students when acting simultaneously. The results showed that only three of the factors were important. Relationships with classmates were the most important. Frictional climate in the class and student-teacher relationships also contributed to maladjustment. The physical facilities of the school and the cohesiveness, competitiveness, and task orientation of the classes did not have detectable effects.

A number of studies (Afsharian \& Kadivar, 2016; Estévez et al., 2018; Garner et al., 2020; Hejazi, Ejei, \& Ranjbar, 2013; Hosseini, 2015; Millings et al., 2012; Saleh-Sedghpour et al., 2011) have indicated that relations with classmates, peer communication and social support are related to maladjustment in the school environment. It appears that weak social bonding in adolescents increases their maladjustment. Hirschi (1969) and more recently Sotoudeh (2007) posited that bonding with individuals and social organizations is one of the ways which a person bonds himself to the society. The weakness of such bonding makes the person feel free to commit maladaptive behaviors. Hence, poor relations to 
classmates would logically be related to maladaptive behavior in school. Whether the relationship is bidirectional or unidirectional remains to be determined.

According to Durkheim's (1895/1950) classic social process view, what causes adolescent maladaptive behavior is the quality of the relationship between adolescents and basic social institutions such as family, peers, and school. Those who have close relationships with parents, friends and teachers develop a positive self-image which enables them to resist the temptations to behave in a deviant way. The data developed here indicate that this is probably correct for relations to classmates and teachers.

Improving the relationships between classmates may be difficult for educators but improving relations between students and their teacher predicts and could produce a reduction in school maladjustment. This finding is consistent with the findings of other researchers (Azin \& Mosavi, 2011; Bae, 2015; Buyse et al., 2008; Kuyumcu, 2020; Moidfar \& Moghimi-Esfandabadi, 2012; Roorda et al., 2020; Rudasill et al., 2010), who considered the supportive relationship between the teacher and the student to be effective in reducing students' maladaptive behaviors. Rostami and Rad (2013) summarized social process theory as indicating that unusual behavior is a function of socialization of individuals. Adolescents are influenced by peer relationships, educational experiences, and interactions with teachers. If these relationships are positive and supportive, the adolescent can play appropriate roles in school well. But if these relationships are destructive, it will be much more difficult to achieve the desired social success, and delinquent solutions will be practical alternatives.

The results of the present research also showed that as the frictional climate of class increases, school maladjustment also increases. In other words, the more unfriendly and frictional the relationships in the classroom, the more maladaptive and unfriendly behaviors the students in the classroom demonstrate. According to Barth et al. (2004) the characteristics of students in a class affect the behavior of students in that class. If a student is in a class that includes many aggressive students, the student is more likely to become more aggressive. The relationship between frictional climate of class and school maladjustment found in the present research are consistent with the results of Periasamy (2021), ZareAlamshiri and Saber (2017), Amanelahi et al. (2009), and Rajabi et al. (2007), who emphasized the effect of classroom climate on student behavior. While some aspects of classroom climate (cohesiveness, task orientation, and competitiveness) did not correlate to maladjustment, friction did. Friction and conflict between students in the classroom can create a negative climate that prevents students from providing positive feedback to each other and reduces empathy and understanding in the classroom. According to the interpretation of Bandura's theory of observational learning offered by Schultz and Schultz (2013), the environment and social contexts are major determinants of behavior. Schools are one of these environments. Students learn different behaviors through implicit learning and observation of the teacher and classmates. The behavior of 
classmates in the classroom and stressful climates that result can contribute to maladjustment. In this study, classroom climate based on competitive orientation, task orientation, and cohesiveness were not significant predictors of school maladjustment. It appears that friendly or unfriendly relations to peers are the most important predictors of maladjustment, according to teachers.

School facilities and space were among the school factors studied in the present research. These were not significant predictors of maladaptive behaviors in the school environment. This finding is consistent with the results of Azin and Mosavi (2011) who also did not find a significant relationship between physical condition of the school and students' maladjustment. However, Bae (2015), Sharif et al. (2011), and Dwyer et al. (2000) did find relationships between these variables. Perhaps the reason for this difference can be sought in the relatively identical context of the sampled schools in the present study. Since the schools were all funded by the city government, the dispersion and variety of facilities and educational space in them were limited.

Limitations in generalizing and interpreting the findings of this research

The study does have the advantage of a random sampling plan, so it can be generalized to a specific population, which is seldom the case for research in education and psychology. It should be noted, however, that findings for a sample to junior high school students in a large city may not apply to other groups and individuals. Research needs to be done on different samples to increase generalizability. Another limitation is that the assessments were done by teachers. Assessments by students or outside observers might have been different. And, of course, while the instruments used here had high reliability and were assessed for validity, other instruments might have yielded higher or lower correlations for the variables measured. The study does have the virtue of measuring seven important variables at the same time. It indicates that one aspect of classroom climate is more important than the others, and indeed was the most important variable measured.

\section{Acknowledgements}

The authors express gratitude to the teachers who graciously assisted with this research.

\section{Supported}

The research reported here was supported in part by the Institute of Education Sciences, U.S. Department of Education, through Grant 305A170114 to George Mason University. The opinions expressed are those of the authors and do not represent views of the Institute or the U.S. Department of Education.

\section{Conflicts of Interest}

The authors declare no conflicts of interest regarding the publication of this paper. 


\section{References}

Afsharian, N., \& Kadivar, P. (2016). The Role of Attachment to Parents and Peers, and Psychological Self-Alienation in Predicting Adolescent's Vandalistic Behaviors. Journal of New Thoughts on Education, 12, 163-184.

Amanelahi, A., Attari, Y. A., \& Khojasteh-Mehr, R. (2009). A Study the Relationship between Family Function and Psycho-Social Atmosphere of the Classrooms with Maladjustment among Male High School Students in Ahvaz. Journal of Counseling Research, 8, 61-78. https://www.sid.ir/en/journal/ViewPaper.aspx?ID=209961

Amirbagloie-Daryani, M., Ganji, H., \& Sharifi, H. P. (2018). Construction and Standardization of a School Maladjustment Scale for High School Students. Developmental Psychology (Journal of Iranian Psychologist), 14, 373-387.

http://jip.azad.ac.ir/article_543920.html

Asadzadeh, H., \& Morovvati, Z. (2007). Recognition of Factors Related to School Dropout in High School Male Students in Abhar. Strategic Studies on Youth and Sports, 8, 105-123. http://ensani.ir/fa/article/download/180031

Azin, A., \& Mosavi, S. M. (2011). Studying the Role of School Factors on Social Adjustment of Students in High School: Fereydounshahr. Journal of Applied Sociology, 22, 183-200. http://jas.ui.ac.ir/article_18221.html

Bae, H. (2015). Bullying Involvement of Korean Children in Germany and in Korea. School Psychology International, 37, 3-17. https://doi.org/10.1177/0143034315605421

Bagheri, M., \& Azemati, H. R. (2011). Improving Children's Creativity in School Environment (Architectural Space as Educational Curriculum). Journal of Curriculum Studies, 6, 163-184. https://www.sid.ir/FileServer/JF/70613902207.pdf

Baker, R. E., \& Siryk, B. (1999). Student Adaptation to College Questionnaire Manual. Western Psychological Services.

Barcaccia, B., Pallini, S., Baiocco, R., Salvati, M., Saliani, A. M., \& Schneider, B. H. (2018). Forgiveness and Friendship Protect Adolescent Victims of Bullying from Emotional Maladjustment. Psicothema, 30, 427-433. http://www.psicothema.com/pdf/4504.pdf

Barth, J. M., Dunlap, S. T., Dane, H., Lochman, J. E., \& Wells, K. C. (2004). Classroom Environment Influences on Aggression, Peer Relations, and Academic Focus. Journal of School Psychology, 42, 115-133. https://doi.org/10.1016/j.jsp.2003.11.004

Berk, L. (2001). Development through the Lifespan (2nd ed.). Allyn \& Bacon.

Bronfenbrenner, U. (1979). The Ecology of Human Development: Experiments by Nature and Design. Harvard University Press.

Buyse, E., Verschueren, K., Doumen, S., Van Damme, J., \& Maes, F. (2008). Classroom Problem Behavior and Teacher-Child Relationships in Kindergarten: The Moderating Role of Classroom Climate. Journal of school Psychology, 46, 367-391. https://doi.org/10.1016/j.jsp.2007.06.009

Cîrceie, E. (2016). Students' School Adjustment/Maladjustment through Preparatory Class. The European Proceedings of Social \& Behavioral Sciences, XVIII, 109-122. https://www.europeanproceedings.com/files/data/article/49/1444/article_49_1444_pdf_ 100.pdf

Cohen, J. (1992) A Power Primer. Psychological Bulletin 112, 155-159. https://doi.org/10.1037/0033-2909.112.1.155

De la Fuente, J., Peralta, F. J., Sánchez, M. D., \& Trianes, M. V. (2012). Validation Study of the Questionnaire on School Maladjustment Problems (QSMP). Psicothema, 24, 330-336. http://www.psicothema.com/pdf/4019.pdf

Durkheim, E. (1895/1950). The Rules of Sociological Method. Free Press. 
Dwyer, K. P., Osher, D., \& Hoffman, C. C. (2000). Creating Responsive Schools: Contextualizing Early Warning, Timely Response. Exceptional Children, 66, 347-365. https://doi.org/10.1177\%2F001440290006600306

Estévez, E., Jiménez, T. I., \& Moreno, D. (2018). Aggressive Behavior in Adolescence as a Predictor of Personal, Family, and School Adjustment Problems. Psicothema, 30, 66-73.

Feigenberg, L. F. (2007). Context Matters: The Influence of School Climate on Early Adolescents' Behavior and Social Development. ProQuest Dissertations \& Theses.

Fraser, B. J. (1994). Handbook of Research on Science Teaching and Learning. Macmillan.

Fraser, B. J., Giddings, G. J., \& McRobbie, C. J. (1995). Evolution and Validation of a Personal Form of an Instrument for Assessing Science Laboratory Classroom Environments. Journal of Research in Science Teaching, 32, 399-422.

https://doi.org/10.1002/tea.3660320408

Garner, P. W., Dunsmore, J. C., \& Bassett, H. H. (2020). Direct and Indirect Pathways to Early School Adjustment: Roles of Young Children's Mental Representations and Peer Victimization. Early Childhood Research Quarterly, 51, 100-109. https://doi.org/10.1016/j.ecresq.2019.09.001

Ghasemzadeh, H. (2016). Social Psychology. Simia Publications.

Gülaçti, F. (2010). The Effect of Perceived Social Support on Subjective Well-Being. Procedia-Social and Behavioral Sciences, 2, 3844-3849.

https://doi.org/10.1016/j.sbspro.2010.03.602

Haj-Shamsayi, M., Kareshki, H., \& Amine-Yazdi, S. A. (2014). Testing the Model of Mediator Role of Self-Regulation in Relation between Classroom Socio-Mental Climate and Maladjustment. Journal of School Psychology, 3, 136-143.

https://www.sid.ir/FileServer/JF/4009113930302.pdf

Hejazi, E., Ejei, J., \& Ranjbar, G. (2013). Predicting School Connectedness Based on Parent and Peers Attachment. Journal of Family Research, 9, 83-97.

http://jfr.sbu.ac.ir/article/view/184

Hirschi, T. (1969). The Causes of Delinquency. The University of California Press.

Hosseini, F. S., \& Latifian, M. (2006). The Joint Effect of Self-Monitoring and Gender on the Psychosocial Climate of the Classroom. Journal of New Thoughts on Education, 2, 27-41. https://www.sid.ir/en/Journal/ViewPaper.aspx?ID=80953

Hosseini, Z. (2015). The Relationship between Family and Friends Social Support and Students' Social Skills and Academic Adjustment. Master's Thesis, Islamic Azad University of Marvdasht. https://ganj.irandoc.ac.ir/

Hossenchari, M., \& Khayer, M. (2003). Classroom Psychological Climate as a Component of School Culture. Journal of Education and Psychology, 9, 25-42. https://www.sid.ir/en/journal/ViewPaper.aspx?ID=25725

Ishee, J. H., \& Alisa, R. J. (2004). Perceptions of Misbehavior in Middle School Physical Education. Journal of Physical Education, Recreation and Dance, 75, 9-18. https://doi.org/10.1080/07303084.2004.10608530

Kiesner, J., \& Kerr, M. (2004). Families, Peers, and Contexts as Multiple Determinants of Adolescent Problem Behavior. Journal of Adolescence, 27, 493-495. https://psycnet.apa.org/doi/10.1016/j.adolescence.2004.06.004 https://doi.org/10.1016/j.adolescence.2004.06.004

Kuyumcu, B. (2020). Does Psychological Maladjustment Mediate the Relationship between Students' Perception of Teacher Rejection and Educational Stress? International Journal of Psychology and Educational Studies, 7, 152-164.

https://dergipark.org.tr/en/download/article-file/1335613 
https://doi.org/10.17220/ijpes.2020.02.014

Matthys, W., \& Lochman, J. E. (2010). Oppositional Defiant Disorder and Conduct Disorder in Childhood. John Wiley \& Sons. https://doi.org/10.1002/9780470684382

Millings, A., Buck, R., Montgomery, A., Spears, M., \& Stallard, P. (2012). School Connectedness, Peer Attachment, and Self-Esteem as Predictors of Adolescent Depression. Journal of Adolescence, 35, 1061-1067. https://doi.org/10.1016/j.adolescence.2012.02.015

Moidfar, S., \& Moghimi-Esfandabadi, H. (2012). Survey Educational Factors and Its Influence on Deviance. Journal of Applied Sociology, 23, 1-20.

http://jas.ui.ac.ir/article_18258.html

Musitu-Ferrer, D., Esteban-Ibañez, M., León-Moreno, C., \& García, O. F. (2019). Is School Adjustment Related to Environmental Empathy and Connectedness to Nature? Psychosocial Intervention, 28, 101-110. https://doi.org/10.5093/pi2019a8

Peralta, F. J., Sanchez, M. D., De la Fuente, J., \& Trianes, M. V. (2009). Questionnaire for the Assessment of School Maladjustment Problems (User's Manual). Education \& Psychology I+D+I, e-Publishing Series.

Periasamy, R. (2021). School Climate and Adjustment on Academic Achievement of Higher Secondary School Students with Special Reference to School Related Variables. International Research Journal of Modernization in Engineering Technology and Science, 3, 1000-1005.

https://www.irjmets.com/uploadedfiles/paper/volume3/issue_3_march_2021/6953/162 8083297.pdf

Rajabi, G. H., Chahardolie, H., \& Attari, Y. (2007). The Relationship of Family Functions and Psycho-Social Atmosphere of the Classroom with Maladjustment among the High School Male and Female Students in Malayer. Journal of Education and Psychology, 14, 113-128. https://www.sid.ir/en/journal/ViewPaper.aspx?ID=212201

Rohner, R. P. (2010). Perceived Teacher Acceptance, Parental Acceptance, and the Adjustment, Achievement, and Behavior of School-Going Youth Internationally. CrossCultural Research, 44, 211-221. https://doi.org/10.1177/1069397110366849

Roorda, D. L., Zee, M., \& Koomen, H. M. Y. (2020). Don't Forget Student-Teacher Dependency! A Meta-Analysis on Associations with Students' School Adjustment and the Moderating Role of Student and Teacher Characteristics. Attachment \& Human Development, 23, 490-503. https://doi.org/10.1080/14616734.2020.1751987

Rostami, N., \& Rad, F. (2013). Investigating Social Factors Related to the Tendency of Students to Abnormal Behavior (Study of Female Students in Secondary School in Ahar). Journal of Sociology Studies, 6, 55-75. http://jss.iaut.ac.ir/article_521121.html

Rudasill, K. M., Reio, T. G., Stipanovic, N., \& Taylor, J. E. (2010). A Longitudinal Study of Student-Teacher Relationship Quality, Difficult Temperament, and Risky Behavior from Childhood to Early Adolescence. Journal of School Psychology, 48, 389-412. https://doi.org/10.1016/j.jsp.2010.05.001

Saleh-Sedghpour, B., Asadi, M., \& Miri, M. (2011). The Relationship between Essential Needs and Social Support in Social, Academic and Emotional Adjustment of Student. Journal of Psychology, 14, 401-416.

https://www.sid.ir/Fa/Journal/ViewPaper.aspx?ID=209586

Schultz, D. P., \& Schultz, S. E. (2013). Theories of Personality (10th ed.). Wadsworth, Cengage Learning.

Sharif, R, Ganji, M., \& Hajloo, N. (2011). Role of School Libraries in Students' Bonding and Academic Performance. Journal of Academic Librarianship and Information Research, 45, 59-75. https://www.sid.ir/fa/journal/ViewPaper.aspx?ID=174044 
Sinha, A. K. P., \& Singh, R. P. (1995). Adjustment Inventory for College Students. National Psychological Corporation.

Sotoudeh, H. (2007). Social Pathology. Avayenoor Publications.

Tanyi, M. E. (2002). The Student's Adjustment Inventory Manual. IFE Psychologia, 10, 1-14. https://doi.org/10.4314/ifep.v10i1.23470 https://www.ajol.info//index.php/ifep/article/view/23470

Valka, S. (2015). Management of International Students' Academic Adjustment: Challenges and Solutions. European Scientific Journal, 11, 161-168. http://eujournal.org/index.php/esj/article/view/5219

Waters, S. K., Cross, O. S., \& Runions, K. (2009). Social and Ecological Structures Supporting Adolescent Connectedness to School: A Theoretical Model. Journal of School Health, 79, 516-524. https://doi.org/10.1111/j.1746-1561.2009.00443.x

Zare-Alamshiri, Z., \& Saber, S. (2017). Prediction of Communication Skills Based on Psycho-Social Class Atmosphere and Social Anxiety of High School Students. Community Health, 4, 127-136. https://www.sid.ir/FileServer/JF/3006513960207.pdf 